\title{
Captured on Tape: \\ Interrogation and Videotaping of Detainees at Guantánamo
}

\author{
Mark Denbeaux* \\ Joshua Denbeaux \\ Matthew Darby \\ Adam Deutsch \\ Jennifer Ellick \\ David Gratz \\ Michael Ricciardelli
}

\section{INTRODUCTION ${ }^{1}$}

United States District Court Judge Henry Kennedy issued an order to the government in June 2005 mandating that "all evidence and information regarding the torture, mistreatment, and abuse of detainees now at the United States Naval Base at Guantanamo Bay" be preserved. ${ }^{2}$ Other United States district court judges issued similar

Professor, Seton Hall University School of Law, and Director, Seton Hall University School of Law Center for Policy and Research. The Report also benefited from the research and contributions of Grace Byrd, Jillian Camarote, Douglas Eadie, Shana Edwards, Christopher Fox, John Gregorek, Gabrielle Hughes, Daniel Lorenzo, Daniel Mann, Mark Muoio, Michael Patterson, Courtney Ray, Megan Sassaman, Helen Skinner, and Lauren Winchester.

** Partner, Denbeaux \& Denbeaux. Co-authors Professors Mark Denbeaux and Joshua Denbeaux represent two Guantánamo detainees.

1 This Report was originally published on February 7, 2008, and has not been updated with any subsequent government document releases or Wikileaks information. For future reports by the Seton Hall University School of Law Center for Policy and Research (the "Center"), visit the Center's website at http://law.shu.edu/ProgramsCenters/PublicIntGovServ/policyresearch/Guantan amo-Reports.cfm.

2 Abdah v. Bush, No. 04-1254, 2005 U.S. Dist. LEXIS 17189, at *5 (D.D.C. June 10,2005 ) (order granting injunction to preserve and maintain evidence regarding the treatment of detainees at Guantánamo Bay); see also Context of June-July 2005: Judges Order Bush Administration Not to Destroy Evidence of Torture and Abuse of Detainees, Hist. Commons, http://www.historycommons.org/context.jsp?item=a0605kennedy kessler\#a0605kennedykessler (last visited Sept. 30, 2011). 
orders as early as March 2005. ${ }^{3}$ In November 2005, however, Central Intelligence Agency (CIA) officials destroyed at least two videotapes documenting the interrogations of two Guantánamo detainees. ${ }^{4}$ The destruction of these two tapes occurred not only after the orders were issued, but also after the United States Supreme Court ruled that individuals detained at Guantánamo could pursue habeas corpus actions. ${ }^{5}$ Attempting to ward off judicial inquiry into the destruction of the tapes, the government argued that inquiry by the courts would compromise the Justice Department's investigation of the matter. ${ }^{6}$ On January 24, 2008, however, United States District Court Judge Richard W. Roberts issued an order which became the first to require that the government provide information regarding the tapes' destruction.

Judge Roberts's order did not, however, require the government to provide any information regarding tapes other than the two tapes that the government admitted destroying. Indeed, while judicial inquiry into the destruction of these two tapes is under way, there has not yet been any inquiry by the courts into the existence or destruction of other tapes documenting interrogations conducted at Guantánamo by the CIA. The courts have also not yet inquired about the existence or destruction of taped interrogations conducted by entities other than the CIA that interrogated detainees at Guantánamo.

This Report reveals the following:

- A report issued by a lieutenant general of the United States army indicates that more than 24,000 interrogations were conducted at Guantánamo between 2002 and $2008 .^{8}$

- A second report, produced almost simultaneously by the surgeon general of the United States Army, reveals that

3 See Abdullah v. Bush, 534 F. Supp. 2d 22, 22-23 (D.D.C.), vacated in part, 534 F. Supp. 2d (D.D.C. Feb. 14, 2008) ("[A] preservation order that required respondents to "preserve and maintain all evidence, documents and information, without limitation, now or ever in respondents' possession, custody or control, regarding the individual detained petitioner[] in th[is] case[].'” (second, third, and forth alterations in original)).

${ }^{4}$ Scott Shane, Court Inquiry on Tape Case is Opposed, N.Y. TIMES, Dec. 6, 2007, at 8.

${ }^{5}$ See Rasul v. Bush, 542 U.S. 466 (2004).

${ }^{6}$ Shane, supra note 4.

7 Abdullah, 534 F. Supp. at 22-23; see also Scott Shane, Judge Demands a Report on Destroyed C.I.A. Tapes, N.Y. TIMES, Jan. 25, 2008, at A19.

8 U.S. DeP'T OF Def., ARMy Regulation 15-6: Final Report: InVESTigation InTO FBI Allegations of Detainee Abuse at Guantanamo Bay, Cuba Detention Facility 6 (2005), available at http://www.dod.gov/news/Jul2005/d20050714report.pdf. 
all interrogations conducted at Guantánamo were videotaped. ${ }^{9}$ Thus, many videotapes documenting Guantánamo interrogations do or did exist.

- An infrastructure for videotaping exists at Guantánamo. ${ }^{10}$

- The CIA is just one of many entities that interrogated detainees in Guantánamo. ${ }^{11}$

- Each of these entities has identical motives to destroy taped investigations as did the CIA, and each can apply an identical justification to the destruction of tapes: the entity's interest in "protecting" the interrogators. Any videotapes that may still exist are vulnerable to destruction if they have not already been destroyed. ${ }^{12}$

- Because the government keeps detailed logs of interrogations, it is readily ascertainable which videotapes still exist and which tapes have been destroyed. ${ }^{13}$ Such an inquiry is crucial to the evaluation-as required by Combatant Status Review Tribunal procedures, the Military Commission Act, and the Detainee Treatment Act-of the reliability of hearsay evidence against a detainee. ${ }^{14}$

\section{MANY VIDEOTAPES DOCUMENTING GUANTÁNAMO INTERROGATION DO OR DID EXIST}

On May 24, 2005, Lieutenant General Kevin C. Kiley, M.D.- the surgeon general of the United States Army-issued a report reviewing medical policies at Guantánamo Bay, Operation Enduring Freedom, and Operation Iraqi Freedom. ${ }^{15}$ The report was created because of "concerns regarding the appropriate treatment of detainees, including during interrogation and access to medical care." ${ }^{\text {S16 }}$ Specifically, the report examined "whether detainee medical records were properly maintained; whether medical personnel were aware of detainee abuse and failed to report abuse; and to determine whether

9 Office of the Surgeon Gen., U.S. Army, Final Report: Assessment of DETAINEE MEDICAL OPERATIONS FOR OEF, GTMO, AND OIF § 18-2(d) (2005), available at

http:/ /www1.umn.edu/humanrts/OathBetrayed/Army\%20Surgeon\%20General\%2 0Report.pdf.

See supra Part III.

See supra Part IV.

See supra Part V.

13 See supra notes 45-46 and accompanying text.

See supra notes 47-50 and accompanying text.

15 OfFice OF THE Surgeon GeN., U.S. ARMY, supra note 9.

16 See id. § 2-1(a). 
medical personnel received and/or are currently receiving appropriate training so that they are fully prepared to perform the mission of caring for detainees."

As the surgeon general's report acknowledged, the "revelations of detainee abuse in the Abu Ghraib Detention Facility in Iraq.... [and] reports in the press [that] have alleged wrongdoing by military medical personnel" created an increased awareness of the military's interrogation procedures. ${ }^{18}$ Indeed, the New England Journal of Medicine reported concerns regarding military doctors' treatment of prisoners. ${ }^{19}$ And in 2004, the American Medical Association "support[ed] calls for a new investigation into whether doctors were complicit in the torture of prisoners held by U.S. military forces in Iraq and Afghanistan. ${ }^{20}$

Lieutenant General Kiley's report arose out of the medical community's concerns and was released in May 2005. Chapter 18 of the report contains a section labeled "Overview of Site Visits to Afghanistan (OEF), Cuba (GTMO), and Iraq (OIF)"; Subsection 18-2 addresses specifically the site visits to Guantánamo Bay. ${ }^{21}$ Within Section $18-2$, the report notes that " $[\mathrm{m}]$ edics randomly observe interrogations and have the ability to halt an interrogation at any point they deem necessary." ${ }^{22}$ The same section of the report assures that: "[a]ll interrogations are videotaped."

On June 9, 2005, within weeks of the release of Lieutenant General Kiley's report, Lieutenant General Randall Schmidt produced an amended report which reviewed FBI allegations of detainee abuse at Guantánamo Bay. ${ }^{24}$ According to Lieutenant General Schmidt's report, more than 24,000 interrogations had been completed at Guantánamo Bay since 2002. ${ }^{25}$ Together, these two reports-which were released almost simultaneously-indicate that the government conducted and videotaped more than 24,000 interrogations at Guantánamo Bay.

\footnotetext{
17 Id. $\$ 2-1(\mathrm{~d})$.

18 Id. $§ 2-1(\mathrm{a})$.

${ }^{19}$ Robert Jay Lifton, Doctors and Torture, 351 New Eng. J. Med. 415, 415-16 (2004), available at http://content.nejm.org/cgi/content/full/351/5/415.

${ }^{20}$ Susan Mayor, AMA Calls for Inquiry Into Doctors' Role in Abuse of Prisoners', 329

BRIT. MED. J. 993, 993 (2004), available at http://www.bmj.com/content/329/7473/993.1.full.

${ }^{21}$ OfFice OF THE SuRgeON GEN., U.S. ARMY, supra note $9, \S 18-1$.

${ }^{22} I d . \S 18-2(\mathrm{~d})$.

${ }^{23}$ Id. (emphasis added).

${ }^{24}$ U.S. DEP'T OF DEF., supra note 8.

${ }^{25}$ Id. at 6 .
} 


\section{VIDEOTAPING INFRASTRUCTURE AND POLICIES}

Records indicate that an infrastructure for videotaping exists at Guantánamo. Cameras are positioned in every interrogation room, and each room is monitored from elsewhere, as illustrated by the following:

[REDACTED] and I were in monitoring room 5 in gold building observing the approach of [REDACTED] a fellow interrogator. [REDACTED] was interrogating in interrogation room 4. Monitoring room 5 overlooks both interrogation room 4 and interrogation room $6 .^{26}$

Many other documents reference the Closed Circuit Television (CCTV) system at Guantánamo Bay. As just one more example, a special agent for the Federal Bureau of Investigation (FBI) documented the following:

Got called out the other night for [REDACTED]. He called the guards and said he wanted to talk to somebody now. We watched him groom himself and prayer-up for his "meeting." [An Agent, REDACTED] and a linguist went over and $\mathrm{E} \& \mathrm{I}$ watched on the video monitor.... We continue to review the files, consult with the teams and continue the work at Delta. ${ }^{27}$

In fact, the Defense Department's "Standard Operating Procedures for Guantánamo's Camp Delta" mandated that "monitors will observe all interrogations" and that monitors "will be located either in a monitor room that is equipped with two way mirrors and CCTV or in a CCTV only room." ${ }^{28}$ Thus, an infrastructure for taping exists at Guantánamo.

Additionally, agencies that interrogated detainees at Guantánamo have policies encouraging, if not requiring, videotaping of interrogations. The policy of the Department of Defense's Criminal Investigation Task Force (CITF), for instance, notes the department's strong preference for videotaping final interviews with detainees who are being transferred and who are potential witnesses. ${ }^{29}$ Exceptions

\footnotetext{
${ }^{26}$ Memorandum from [REDACTED], to [REDACTED](Apr. 28, 2003) (alterations in original) (on file with author).

${ }^{27}$ E-mail from [REDACTED], to [REDACTED] (Aug. 28, 2002, 12:23 PM) (alterations in original) (on file with author).

${ }^{28}$ Joint Task Force-Guantánamo, U.S. DeP'T of Def., Camp Delta Standard Operating Procedures (SOP) $\$ \quad 14-12 \quad$ (2003), available at http://www.comw.org/warreport/fulltext/gitmo-sop.pdf.

${ }^{29}$ Memorandum from Brittain P. Mallow, Colonel, U.S. Army, for All Assigned to the DOD Criminal Investigation Task Force to Task Force Commander, (Oct. 3, 2003), available http://dspace.wrlc.org/doc/bitstream/2041/64362/01024display.pdf.
} 
to this policy, in fact, require special approval. ${ }^{30}$ This policy is stated in a document identified as the "CITF Memorandum for All Personnel Assigned to the DoD Criminal Investigation Task Force" dated October 3, 2003, and signed by Brittain P. Mallow, Colonel Military Police:

2. (U) The purpose of this memorandum is to reiterate my previous guidance to Criminal Investigation Task Force (CITF) personnel, related to the conduct of interrogations of detainees or persons under custody. For the purpose of this memorandum all references to detainees will also apply to persons under custody.

...

4. Interrogation:

f. (U) Photographs and or video recordings of interrogations are not required as a matter of policy; however, they may be generated at the discretion of the agent conducting the interview with the concurrence of the RAC ["“Resident Agent in Charge"“]. CITF personnel may consider videotaping the final interview with detainees who are to be released / transferred and will strongly consider videotaping a final interview of any detainee who is being transferred who has possible value as a witness. Exceptions to this policy must be approved by CITF-HQ at the Commander (CDR) or Deputy Commander (DCO) level. The DCO is also the Senior Agent in Charge (SAC). ${ }^{3.1}$

Thus, the videotaping of interrogations was clearly authorized by the CITF, and in some very important cases (that is, when a transferred detainee was perceived as a potential witness), disallowed only with permission.

There were, of course, many different agencies with their own procedures and policies with regard to videotaping. As an example of another agency's policies, the Army Field Manual for Human Intelligence Collection Operations (HUMINT) ${ }^{32}$ states HUMINT's preference for videotaping as a means of recording interrogations:

Video recording is possibly the most accurate method of recording a questioning session since it records not only the voices but also can be examined for details of body language and source and collector interaction. ${ }^{33}$

${ }^{30} \quad I d$. at 1 .

${ }^{31} \quad I d$. at 1-2(emphasis added).

${ }^{32}$ HUMINT was one of multiple agencies that interrogated detainees at Guantánamo. See discussion infra Part IV.

33 U.S. DeP'T of the ARMy, Human Intelligence Collector Operations 9-11 (2006) available 
Interestingly, the two potential drawbacks of videotaping - that filming requires equipment, and that cameras might inhibit a source-do not apply to Guantánamo because (a) the detainees were already being "monitored" by cameras, and (b) the detainees already believed that they were being filmed. One agent for the FBI, for instance, reported the following:

During a prior interview (FD-302 dated 10/26/2002) [REDACTED] made the comment: "I got out of the circle and now I am in chains." He was asked about the meaning of the comment. He said he did not remember the reason he said it and asked to be told what the comment was in relation to. When told that it concerned [REDACTED and REDACTED, REDACTED] became defensive and stared at the ground. He told the interviewers to "check the tapes," referring to his belief that all interviews are videotaped.

Thus, the policies as well as the infrastructure in place at Guantánamo support the videotaping of interrogations.

\section{THE CIA Is JUST ONE OF MANY INTELLIGENCE-GATHERING AGENCIES TO HAVE INTERROGATED DETAINEES ON CAMERA}

The following federal agencies or bureaus conducted interrogations at Guantánamo: the Central Intelligence Agency (CIA) and its Counterterrorism Center (CITF), the FBI, the Behavioral Analysis Unit of the FBI (BAU), the Defense Intelligence Agency (DIA), the HUMINT, the Army Criminal Investigative Division (ACID), the Air Force Office of Special Investigations (OSI), and the Naval Criminal Investigative Service (NCIS). ${ }^{35}$ In addition, private contractors interrogated detainees. ${ }^{36}$ As just one example of the number of entities engaged in interrogations of Guantánamo detainees, the following is excerpted from an incident report filed on April 26, 2003, by an analyst for a private contractor hired by the Defense Department, in which the analyst reported abuse of a prisoner-not by a CIA agent, but by U.S. Army and Navy analysts-in a video-monitored interrogation room:

${ }^{34}$ E-mail from [REDACTED], to [REDACTED] ([REDACTED]) (alterations in original) (on file with author).

${ }_{35}$ Fed. Bureau of Investigation, Detainees Positive Responses 69-73, 176, 214 (2004), available http://vault.fbi.gov/Guantanamo\%20/Guantanamo\%20Part\%201\%20of\%201/view

${ }_{36}$ See Griff Witte \& Renee Merle, Contractors Are Cited in Abuses at Guantánamo, WASH. Post, Jan. 4, 2007, at D1. The first private contractor hired to interrogate detainees was Affiliated Computer Systems (ACS). Id. ACS was later replaced by Chenega. $I d$. 
When we walked into a monitoring room, we saw another interrogation in room 7 was going on. In the monitoring room was a female Army analyst and a male Navy analyst. The Army analyst was controlling the monitor and had a speaker so that both parties could hear the interrogation. The speaker was loud enough that I could hear it muffled even though I had headsets on. In the interrogation room was the interrogator [REDACTED], a male Navy interpreter, two male MPs and the detainee. ${ }^{37}$

This Guantánamo Bay interrogation was conducted not by the CIA, but by the Army and the Navy, and was reported by a private contractor for the Department of Defense who was also an interrogator.

Additionally, on September 14, 2004, an FBI agent from the Counterterrorism Division issued a report to FBI headquarters in response to a query as to whether he had witnessed any abuse toward prisoners during interrogations. In his response, the agent described incidents involving the ACID, OSI, and the NCIS, all of which, he indicated, were involved in interrogations at Guantánamo. ${ }^{38}$ In the same report, the FBI agent indicated that the employees of the NCIS checked with the NCIS's attorneys to determine whether harsh or aggressive interrogation techniques were permitted to be used on the prisoners. $^{39}$ While the agent was unclear as to whether he witnessed the NCIS employees engage in abuse, the agent stated in the report that harsh techniques were used by DIA / DHS. ${ }^{40}$

Notwithstanding the diverse entities involved in interrogation at Guantánamo, the government has not acknowledged that the Department of Defense, the FBI, or any entity other than the CIA taped interrogations of detainees. Tapes produced by any of these other entities-and indeed, tapes produced anywhere at Guantánamo-do not fall within the scope of the Justice Department's narrow investigation into the matter of the two videotapes destroyed by the CIA.

${ }^{37}$ Letter from T.J. Harrington, Deputy Assistant Dir., Fed. Bureau of Investigation, to [REDACTED] (Nov. 4, 2004) [hereinafter Harrington Letter], available at http://www.aclu.org/files/projects/foiasearch/pdf/DOJFBI002181.pdf; see also Letter from T.J. Harrington, Deputy Assistant Dir., Fed. Bureau of Investigation, to Donald J. Ryder, Major Gen., U.S. Army (July 14, 2004) [hereinafter Ryder Letter], available at http:/ / www.aclu.org/files/projects/foiasearch/pdf/DOJFBI001914.pdf.

38 FED. BuREAU OF InVESTIGATION, supra note 35, at 70.

${ }^{39} \quad$ Id. at 214.

${ }^{40} I d$. at 69-70, 214. "DHS" stands for Defense HUMINT Services. 


\section{ANY VidEOTAPES THAT STILL EXIST ARE VULNERABLE TO DESTRUCTION IF THEY HAVE NOT ALREADY BEEN DESTROYED}

The fact that the government has not provided any videotaped interrogations for evaluation is unsurprising, given the content of some of the videotapes. In fact, one interrogator, aware that her interrogation of a detainee was on camera, attempted to shield her actions from view:

She directed a marine to duct tape a curtain over the two-way mirror between the interrogation room and the observation room....Through the surveillance monitor, [Special Agent, REDACTED] then observed [REDACTED] position herself between the detainee and the surveillance camera.

One can only guess what interrogation techniques the agent was trying to hide from the cameras.

Leaving less to the imagination is the following record of another interrogation, documented by an ex-military civilian contractor (and interrogator) for the Department of Defense:

They [the detainee, the Navy interpreter, the interrogator, and the two military policemen] were all standing in the center of the floor. The MPs held the detainee by the upper arms. The interpreter was standing to the rear of the detainee and [REDACTED] was standing directly in front of the detainee. [REDACTED] was yelling questions at the detainee very rapidly, [REDACTED] yelled "DOWN." The MPs then pushed the detainee to the floor with enough force to not only shake the camera in the interrogation room, but also in the room that [REDACTED] was conducting his interrogation. He would then yell "GET UP," and the MPs would jerk the detainee up. Each time the female analyst first heard the word "DOWN" [REDACTED] the analyst in the monitoring room stood up to watch this as it was happening and was laughing about it. ${ }^{42}$

Another report gave a similar description:

[REDACTED] then shouted "DOWN" and the two detainee escorts pushed the detainee to the floor. When I say pushed to the floor I mean they pushed in the back of the detainee's knees with their knees, taking the detainee to his knees. Then holding the detainee by his upper arms they slam ed his upper body to the floor. This series of motions was all done in one swift movement, so that the detainee went from a standing position to a prone position all at once. The force with which the detainee's body hit

${ }^{41}$ Harrington Letter, supra note 37; see also Ryder Letter, supra note 37.

42 Memorandum from [REDACTED], Analyst, Amidon Contracting Solutions, Inc., to [REDACTED] (Apr. 22, 2003) (alterations in original) (emphasis added) (on file with author). 
the floor was such that [REDACTED, REDACTED, REDACTED, REDACTED, REDACTED, REDACTED, REDACTED, REDACTED, REDACTED, REDACTED, REDACTED] was interrogating. Immediately before the detainee was pushed to the floor, [REDACTED, REDACTED, REDACTED, REDACTED, REDACTED, REDACTED, REDACTED, REDACTED] and the Navy analyst were laughing about the treatment of the detainee.... The force with which the detainee hit the floor was, in my estimation, adequate to cause severe internal injury. I left the monitoring room. ${ }^{43}$

Clearly, descriptions of the physical trauma exacted upon the prisoner by Department of Defense officials were redacted not because of concern for national security, but rather because of concern for the department's potential liability. A natural corollary to that concern is an even greater desire to destroy any filmed evidence of whatever was redacted. In the words of a former senior CIA official: "It's a qualitatively different thing-seeing it versus reading about it."

\section{The GOVERnMENT KePt METICUlOUs ReCORDS OF ALL INTERROGATIONS}

The name of each detainee, the identity of each interrogator, and the date, time, and place of each interrogation were meticulously recorded in logs. One FBI special agent stated, in response to an FBI special inquiry, that, while he did not know the identity of a particular "bleeding detainee" or the personnel who interrogated the detainee, the agent believed that:

determining their identities would be possible by querying logs maintained by the military at GITMO. According to SA [REDACTED], the date, interviewing room, and the identities of the interviewers and detainees for each interview were maintained by the military at GITMO. ${ }^{45}$

Predictably, identifying details pertinent to the interrogations were logged in detail by the FBI and by the Department of Defense. Department of Defense employees could even request and obtain tran-

${ }^{43}$ Memorandum from [REDACTED], Interrogator, Amidon Contracting Solutions, Inc., to [REDACTED] 1-2 (Apr. 26, 2003) (alterations in original) (emphasis added) (on file with author).

${ }^{44}$ Kevin Whitelaw, The New CIA Acts a Bit Like the Old CIA, U.S. NEws \& WorLD REP. (Dec. 24, 2007), at 26, available at http://www.usnews.com/news/articles/2007/12/13/the-new-cia-acts-a-bit-like-theold-cia.

${ }^{45}$ Fed. Bureau of InVEStigation, supra note 35, at 72. 
scripts, reports and after-action interviews of any and all interviews conducted by other agencies and entities to determine the law enforcement value of the information and the effectiveness of the interrogation strategies employed. ${ }^{46}$ Thus, to determine what was videotaped and which tapes were destroyed would not be burdensome for the government.

\section{CONCLUSION}

Combatant Status Review Tribunal procedures, ${ }^{47}$ the Military Commission Act, ${ }^{48}$ and the Detainee Treatment $\mathrm{Act}^{49}$ all require that the reliability of the evidence against a detainee be evaluated. The reliability of hearsay evidence, in particular, must be evaluated..$^{50}$ The taped interrogations recorded at Guantánamo Bay are equally as important to evaluating the reliability of the evidence against a detainee as were the two videotapes destroyed by the CIA. Judge Roberts's order represents an important shift from the court's reliance upon the government's self-investigation, but-like the investigation itself-it applies only narrowly. Judicial and perhaps congressional inquiry is necessary-not only into the publicized destruction of two videotapes, but with respect to the many other taped interrogations which either still exist or were destroyed.

${ }^{46} I d$. at 69-73, 176, 214.

47 See Memorandum from the Deputy Sec'y of Def. to the Sec'ys of the Military Dep'ts, et al., at Enclosure (1), G(7) (July 14, 2006).

${ }^{48}$ See 10 U.S.C. $\$ 949$ (a) (Supp. III 2009).

${ }^{49}$ See Pub. L. No. 109-148, § 1005(e), 119 Stat. 2739, 2742 (codified as amended at 28 U.S.C. $\$ 2241(\mathrm{e}))$.

${ }^{50}$ This rule was not followed the first time around, however. See Declaration of Lieutenant Stephen Abraham, Al Odah v. United States, 551 U.S. 1161 (2007), available at http://humanrights.ucdavis.edu/projects/the-guantanamo-testimonialsproject/testimonies/testimonies-of-csrt-officers/testimony-of-stephenabraham/Al\%20Odah\%20reply\%206-22-07.pdf (certifying that Combatant Status Review Tribunals did not review all evidence and that exculpatory evidence was withheld). 